\title{
Kekhasan Morfologi Spesies Mangrove di Gili Sulat
}

\author{
Oleh : \\ Agil Al Idrus, I Gde Mertha, Gito Hadiprayitno, dan M. Liwa Ilhamdi \\ Program Studi Pendidikan Biologi \\ Fakultas Keguruan dan Ilmu Pendidikan Universitas Mataram \\ Email: igdemertha@yahoo.co.id
}

\begin{abstract}
ABSTRAK
Tujuan penelitian ini adalah menganalisis kekhasan morfologi spesies mangrove di Gili Sulat. Pengumpulan data dalam penelitian ini menggunakan metode survey melalui pengamatan langsung secara in situ terhadap morfologi populasi-populasi dalam spesies mangrove di lapangan. Data yang diperoleh dianalisis secara kualitatif dan kuantitatif kemudian deskripsikan untuk menggambarkan kekhasan morfologi spesies mangrove di Gili Sulat. Hasil penelitian menunjukkan terdapat tujuh spesies mangrove komponen mayor yang populasinya menunjukkan morfologi yang khas di Gili Sulat, yaitu Bruguiera gymnorrhiza, Rhizophora mucronata, Rhizophora stylosa, Rhizophora apiculata, Ceriops tagal, Sonneratia alba, dan Avicennia marina. Kekhasan morfologi spesies mangrove tersebut mencakup karakter tinggi pohon, warna dan diameter batang, struktur akar dan jumlah bunga.

Kata kunci: kekhasan, mangrove, morfologi
\end{abstract}

\begin{abstract}
The aims of this reseach is to analyze specific morphology of species mangrove in Gili Sulat. Data collected in this reseach is done by survey method through in situ observation to populations morphology of mangrove species in the field. Data is analyzed by qualitative and quantitative and then describing to explain specific morphology of mangrove species in Gili sulat. The result show that there are seven major component of mangrove species with specific population morphology in Gili sulat, namely Bruguiera gymnorrhiza, Rhizophora mucronata, Rhizophora stylosa, Rhizophora apiculata, Ceriops tagal, Sonneratia alba, and Avicennia marina, respectively. The specific morphology character of these mangrove species are heigh of trees, colour and diameter of stem, root structure and number of flower.
\end{abstract}

Key Words: specific, mangrove, morphology

\section{PENDAHULUAN}

$\mathrm{M}$

angrove memiliki karakter morfologi yang unik sebagai bentuk adaptasi terhadap kondisi lingkungan tempat tumbuhnya. Kondisi substrat dan salinitas merupakan dua faktor penting yang harus diatasi oleh tumbuhan mangrove agar bisa tetap eksis. Kedua faktor tersebut berkonstribusi dalam memicu adaptasi tumbuhan mangrove secara morfologi dan fisiologi. Respon morfologi yang ditunjukkan tumbuhan mangrove, antara lain dengan membentuk sistem perakaran dan buah yang unik. Respon fisiologi ditandai dengan terbentuknya struktur anatomi yang khas pada daun, misalnya adanya kelenjar garam dan mekanisme yang unik dalam pengeluaran garam. 
Bentuk morfologi akar, buah, dan anatomi pada tumbuhan mangrove merupakan karakter taksonomi yang mantap. Hal ini berarti bahwa bentuk morfologi ketiga karakter tersebut selalu ada pada tumbuhan mangrove dan secara genetik diturunkan dari satu generasi ke generasi berikutnya. Dengan demikian macam-macam tipe akar seperti akar tunjang, akar pensil, akar papan, dan akar lutut merupakan bentuk spesialisasi morfologi yang cukup valid sebagai penanda takson tertentu pada mangrove. Demikian pula morfologi buah yang membentuk berbagai variasi propagul dapat digunakan sebagai karakter yang berharga untuk membedakan kelompok pada mangrove (Tomlinson, 1986). Sifat morfologi mangove tersebut pada lokasi yang berbeda-beda tidak mengalami perubahan sehingga menjadi ciri taksonomi khas mangrove, khususnya pada tingkatan famili, marga dan spesies.

Pada tingkatan spesies, tidak semua anggota populasi yang membentuk spesies taksonomi memiliki karakter homogen (Hardjosuwarno, 1990). Ciri-ciri morfologi dan kimia atau fisiologi yang ditampilkan oleh kelompok-kelompok populasi spesies dapat berbeda satu sama lain sebagai respon terhadap keadaan ekologi tertentu (Barbour et al., 1980). Hasil penelitian Turesson (1922) dalam Hardjosuwarno (1990) menunjukkan bahwa variasi pada anggota populasi suatu spesies adalah sebagai produk tanggapan genetik terhadap habitat dalam kisaran jenis. Berdasarkan hal tersebut, terdapat dua tipe populasi tumbuhan sebagai bentuk respon terhadap kondisi habitat tertentu, yaitu ekotipe (ecotype) dan ekofen (echopene). Respon morfologi dan fisiologi pada ekotipe diturunkan kepada generasi berikutnya (heritable), sehingga tipe populasi ini akan mempertahankan keistimewaan asalnya bila ditanam dalam habitat lain. Populasi yang keunikannya di alam disebabkan karena plastisitas nongenetis disebut ekofen atau fenekotipe (phenecotype), untuk membedakan dari ekotipe.

Pengamatan para pakar botani terhadap keanekaragaman tumbuhan mangrove umumnya terbatas pada spesies taksonomi, jarang sekali yang memperhatikan spesies ekologi (ras ekologis), seperti ekotipe dan ekofen serta varian genetik individu atau grup individu dalam ekotipe yang disebut biotipe. Walaupun ras ekologi secara taksonomi dianggap kurang berarti karena karakteristik habitat sebagai dasar penentuan spesies tersebut belum atau jarang dianggap penting sebagai kriteria taksonomi, namun data ekotipe dan ekofen sangat penting bagi ekologiawan tumbuhan sebagai alat deduktif untuk dapat memahami ekosistem, misalnya dalam menunjang dinamika populasi spesies, analisis kondisi lingkungan serta proses mikroevolusi (Hardjosuwarno, 1990). Selain itu, data tersebut merupakan informasi yang sangat berharga dalam menentukan kekhasan mangrove pada suatu lokasi.

Gili Sulat merupakan pulau di sebelah timur bagian utara Pulau Lombok dengan luas 1200 hektar yang sebagian besar arealnya terendam air sebagai habitat mangrove. Hutan mangrove di Gili Sulat dihuni banyak spesies mangrove. Jumlah itu termasuk paling banyak di Indonesia. Beberapa jenis mangrove komponen mayor di Gili Sulat menunjukkan penampilan morfologi yang cukup menarik untuk diamati, sehingga perlu dilakukan kajian botani pada tingkat populasi untuk mengungkap variasi morfologi mangrove di kawasan tersebut (Agil, 2013). Pengamatan terhadap kekhasan karakter morfologi spesies mangrove yang berhubungan dengan ras ekologis di Gili Sulat belum banyak diungkapkan. 


\section{BAHAN DAN METODE}

Penelitian ini dilakukan pada kawasan hutan mangrove Gili Sulat Kabupaten Lombok Timur pada bulan April - Juni 2014. Kegiatan lapangan dalam penelitian ini dilakukan sebanyak enam kali dalam rentang waktu tersebut.

Pengumpulan data dalam penelitian ini menggunakan metode survey melalui pengamatan langsung secara in situ terhadap kondisi morfologi mangrove di lapangan. Pengambilan data dilakukan pada saat kondisi perairan mengalami surut maksimal, sehinggsa memudahkan dalam perjalanan memasuki kawasan hutan mangrove. Selain itu pada kondisi demikian struktur morfologi akar akan tampak lebih lengkap dan jelas.

Alat yang digunakan dalam pengambilan data penelitian, yaitu meteran, gunting tanaman, teropong, kamera digital, hagameter dan parang. Alat-alat tersebut digunakan untuk mengukur keliling batang pohon, mengambil spesimen, mengamati pohon dalam jarak jauh, dokumentasi hasil penelitian, mengukur tinggi pohon dan membuka jalan pada hutan mangrove untuk menemukan jenis yang akan diamati.

Parameter yang diamati dalam penelitian ini dan cara pengukurannya adalah sebagai berikut: tinggi pohon ditentukan dengan mengukur menggunakan hagameter, warna kulit batang dengan pengamatan langsung, keliling batang (untuk menentukan diameter) diukur menggunakan meteran, morfologi akar (akar lutut, akar sangga, pneumatofora) dengan pengamatan langsung, ukuran akar ditentukan dengan mengukur akar menggunakan meteran, dan jumlah bunga setiap tandan dengan pengamatan langsung di lapangan.

Data yang diperoleh dibandingkan dengan morfologi spesies mangrove dalam buku Handbook of Mangroves in Indonesia - Bali \& Lombok yang ditulis Kitamura et al. (1997) dan selanjutnya dilakukan analisis secara kualitatif dan kuantitatif. Hasil analisis deskripsikan untuk menggambarkan kekhasan morfologi populasi spesies mangrove di Gili Sulat.

\section{HASIL DAN PEMBAHASAN Gambaran umum morfologi mangrove}

Hasil penelitian menunjukkan terdapat 7 spesies mangrove komponen mayor yang menunjukkan variasi morfologi yang unik di Gili Sulat (Tabel 1). Dari tujuh spesies mangrove tersebut, enam spesies menunjukkan perbedaan karakter morfologi dengan spesies pada Kitamura et al. (1997) pada Tabel 2. Satu spesies yang lain memiliki ciri morfologi yang masih berada dalam kisaran deskripsi Kitamura et al. (1997), namun membentuk dua kelompok populasi yang cukup tegas perbedaan morfologinya. Kekhasan lima spesies mangrove di Gili Sulat tersebut terdapat pada karakter tinggi pohon, warna dan diameter batang, akar, dan bunga.

Kekhasan morfologi yang paling menonjol pada mangrove di Gili Sulat adalah tinggi pohon. Berdasarkan data tinggi pohon tujuh spesieas mangrove di Gili Sulat (Tabel 1), lima spesies $(71,43 \%)$ menunjukkan ciri yang berbeda dengan spesies pada Kitamura et al. (1997). Masing-masing spesies mangrove tersebut adalah Bruguiera gymnorrgiza, Rhizophora mucronata, Rhizophora stylosa, Rhizophora apiculata, dan Sonneratia alba.

Ciri batang spesies mangrove di Gili Sulat hampir seluruhnya tidak berbeda dengan ciri batang pada Kitamura et al. (1997). Keunikan warna kulit batang hanya ditemukan pada satu jenis, yaitu pada Bruguiera gymnorrhiza yang menunjukkan warna abu gelap. Ukuran 
diameter batang yang mencapai $150 \mathrm{~cm}$ pada Sonneratia alba dapat dijadikan sebagai salah satu kekhasan mangrove di
Gili Sulat (Tabel 1), karena diameter batang sebesar itu belum pernah ditemukan di Pulau Lombok.

Tabel 1. Data hasil pengamatan morfologi spesies mangrove di Gili Sulat, 2014.

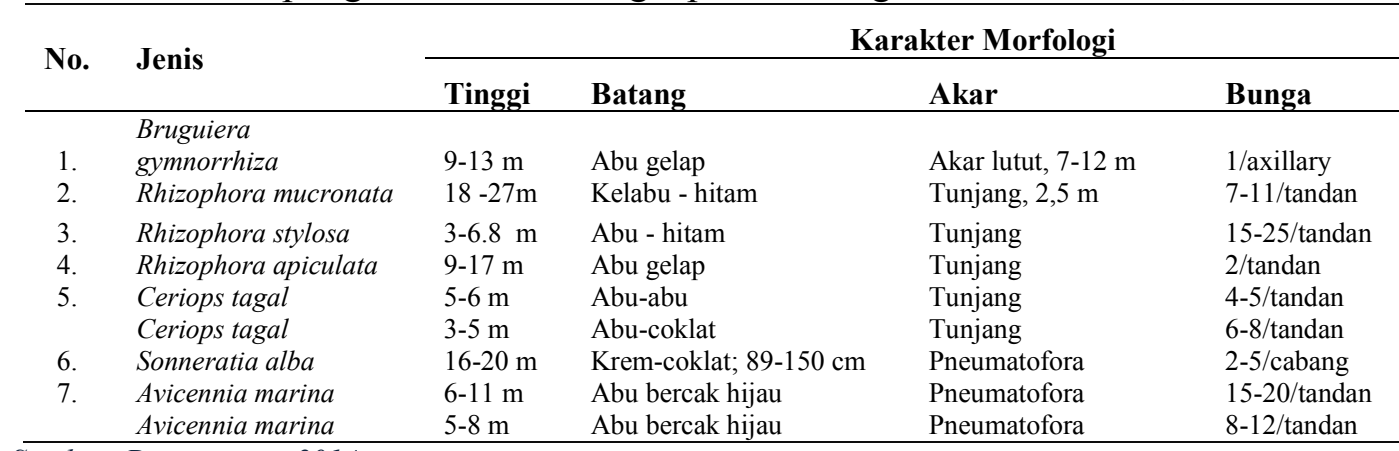

Sumber: Data primer, 2014

Tabel 2. Morfologi spesies tumbuhan mangrove di Pulau Bali dan Pulau Lombok menurut Kitamura et al., 1997.

\begin{tabular}{|c|c|c|c|c|c|}
\hline \multirow{2}{*}{ No. } & \multirow{2}{*}{ Jenis } & & \multicolumn{3}{|c|}{ Karakter Morfologi } \\
\hline & & Tinggi & Batang & Akar & Bunga \\
\hline 1. & Bruguiera gymnorrhiza & Sampai $12 \mathrm{~m}$ & Abu & Akar Lutut & 1/axillary \\
\hline 2. & Rhizophora mucronata & Sampai $25 \mathrm{~m}$ & Kelabu - hitam & Tunjang & 4-8/tandan \\
\hline 3. & Rhizophora stylosa & Sampai $6 \mathrm{~m}$ & $\mathrm{Abu}$ - hitam & Tunjang & 8-16 atau lebih/tandan \\
\hline 4. & Rhizophora apiculata & Sampai $15 \mathrm{~m}$ & Abu - Abu gelap & Tunjang & 2/tandan \\
\hline 5. & Ceriops tagal & Sampai $6 \mathrm{~m}$ & Abu-abu - coklat & Tunjang & $5-10 / \operatorname{tandan}$ \\
\hline 6. & Sonneratia alba & Sampai $16 \mathrm{~m}$ & Krem,-coklat & Pneumatofora & 1-beberapa/cabang \\
\hline 7. & Avicennia marina & Sampai $12 \mathrm{~m}$ & Abu bercak hijau & Pneumatofora & $8-14 / \operatorname{tandan}$ \\
\hline
\end{tabular}

Sumber: Handbook of Mangroves in Indonesia - Bali \& Lombok, 1997.

Bentuk akar mangrove merupakan ciri taksonomi yang mantap (Tomlinson, 1986). Semua ciri morfologi akar pada populasi spesies mangrove yang terdapat di Gili Sulat (Tabel 1) sama dengan ciri yang terdapat dalam Kitamura et al. (1997), kecuali pada ukuran akar. Ukuran akar mangrove pada Bruguiera gymnorrhiza cukup menarik untuk diamati karena memiliki panjang yang menyebar sampai radius 12 meter dari tumbuhan induk. Demikian pula morfologi akar Rhizophora mucronata dan Sonneratia alba yang berukuran cukup besar, tidak dijumpai di tempat lain di Pulau Lombok.

Jumlah bunga pada setiap tandan menunjukkan kesamaan yang besar antara ciri yang terdapat dalam Kitamura et al. (1997) dengan hasil penelitian di Gili Sulat (Tabel 1). Spesies mangrove yang menunjukkan ciri bunga yang sama seperti pada Tabel 2, yaitu Bruguiera gymnorrhiza, Rhizophora stylosa, Rhizophora apiculata, ceriops tagal, dan satu populasi spesies pada Avicennia marina. Sedangkan spesies yang jumlah bunganya pada setiap tandan berbeda dengan Tabel 2 adalah Rhizophora mucronata dan satu populasi pada spesies Avicennia marina.

Kekhasan morfologi jenis mangrove

Ciri khas morfologi jenis mangrove yang terdapat di Gili Sulat sebagai berikut: 


\section{Bruguiera gymnorrhiza (L.) Lam.}

Bruguiera gymnorrhiza yang terdapat di Gili Sulat berupa pohon yang cukup besar dengan tinggi antara 9-3 m. Pohon spesies ini yang mencapai tinggi $13 \mathrm{~m}$ hanya ditemukan di Gili Sulat (Tabel 1). Populasi spesies Bruguiera gymnorrhiza yang terdapat di Pulau Lombok hanya mencapai tinggi sampai 12 meter (Tabel 2). Berdasarkan data tersebut maka tinggi pohon yang mencapai $13 \mathrm{~m}$ dalam populasi Bruguiera gymnorrhiza adalah khas untuk mangrove di Gili Sulat.

Akar Bruguiera gymnorrhiza melebar ke samping pada radius 7-12 m dari bagian pangkal pohon (Tabel 1). Sepanjang akar tersebut muncul sejumlah akar lutut. Panjang akar yang memanjang ke arah samping mencapai $12 \mathrm{~m}$ belum pernah dilaporkan keberadaanya pada ekosistem mangrove lain di Pulau Lombok. Ukuran akar Bruguiera gymnorrhiza yang diperoleh pada penelitian ini lebih panjang dibanding akar populasi spesies tersebut yang pernah diamati Agil (2013) di Gili Sulat yang mencapai ukuran maksimal sampai 9 meter.

Pohon Bruguiera gymnorrhiza yang terdapat di Gili Sulat merupakan populasi mangrove yang berumur cukup tua. Berdasarkan informasi masyarakat, pohon Bruguiera gymnorrhiza tersebut diperkirakan telah berumur lebih dari 45 tahun. Pohon mangrove yang telah berumur cukup tua ini dicirikan dengan kulit batang yang berwarna abu gelap (Tabel 1). Warna kulit batang mangrove tersebut berbeda dengan kerabat dekatnya yang terdapat pada tempat lain di Pulau Lombok.

\section{Rhizophora mucronata Lam.}

Rhizophora mucronata merupakan tumbuhan mangrove yang memiliki tajuk paling tinggi di Gili Sulat. Kisaran tinggi pohon mangrove ini antara $18-27 \mathrm{~m}$. Pohon mangrove yang mencapai tinggi 27 $m$ tersebut adalah khas untuk Gili Sulat. Tinggi maksimum pohon mangrove Rhizophora mucronata di Pulau Lombok yang pernah dilaporkan yaitu mencapai 25 m (Kitamura et al., 1997).

Akar tunjang Rhizophora mucronata tampak sangat mencolok di Gili Sulat. Tampilan morfologi akar tunjang populasi spesies tersebut berbeda dengan populasi yang terdapat di pesisir Pulau Lombok. Ukuran akar tunjang pohon dewasa pada populasi Rhizophora mucronata yang terdapat di Gili Sulat dapat mencapai tinggi 2,5 meter, sedangkan populasi yang terdapat di pesisir Pulau Lombok memiliki akar tunjang yang tingginya kurang dari 1,5 meter. Selain ciri akar tunjang yang cukup tinggi, bagian akar yang terdapat pada pangkal batang cukup unik karena melebar seperti papan. Ciri morfologi akar tersebut dapat digunakan sebagai penanda khas Rhizophora mucronata di lapangan.

Kulit batang Rhizophora mucronata berwarna kelabu sampai hitam. Pohon yang masih muda berkulit kelabu, sedangkan pohon yang telah tua kulitnya berangsur-angsur menjadi hitam dengan retakan-retakan yang sangat jelas. Perubahan warna kulit kayu tersebut berhubungan dengan aktivitas anatomi. Menurut Whitmore (1961), warna dan tekstur kulit kayu dikendalikan oleh periderm selama proses pertumbuhan dan perkembangan tumbuhan.

Jumlah bunga dalam setiap tandan pada Rhizophora mucronata berkisar antara $7-11$. Bunga dalam tandan yang mencapai jumlah sampai delapan, umum ditemukan pada Rhizophora mucronata di Gili Sulat dan pesisir Pulau Lombok (Tabel 2). Populasi dengan jumlah bunga lebih dari delapan dan beberapa mencapai 11 dalam setiap tandan tidak umum ditemukan di Pulau Lombok, kecuali terdapat di Gili Sulat (Tabel 1). Pembentukan jumlah bunga yang tidak 
umum tersebut ada hubungannya dengan konsentrasi florigen (hormon perangsang bunga) yang banyak terbentuk karena kondisi lingkungan di Gili Sulat.

\section{Rhizophora stylosa Griff.}

Rhizophora stylosa merupakan mangrove tepi (fringing mangrove) di Gili Sulat. Populasi spesies ini membentuk sabuk flora yang khas mengelilingi di Gili Sulat. Menurut Agil (2013) kedudukan tegakan Rhizophora stylosa yang berada pada formasi paling depan dan berbatasan langsung dengan laut sangat penting untuk perlindungan komunitas mangrove yang berada di belakangnya. Individu-individu dalam kelompok populasi Rhizophora stylosa tumbuh berdekatan dengan akar tunjang yang cukup rapat. Kondisi akar tersebut sangat penting fungsinya bagi mangrove tepi untuk memecah gelombang.

Populasi spesies Rhizophora stylosa menunjukkan keanekaragaman genetik yang rendah di Gili Sulat. Ciri morfologi tinggi pohon, batang, akar dan jumlah bunga spesies Rhizophora stylosa yang terdapat di Gili Sulat (Tabel 1) tidak menunjukkan variasi yang khas dengan ciri pada Tabel 2. Keanekaragaman genetik yang rendah diduga karean aliran gen yang cukup tinggi dalam populasi Rhizophora stylosa. Aliran gen yang tinggi diduga karena penyerbukan melalui angin. Pertukaran genetik yang tinggi juga disebabkan karena populasi Rhizophora stylosa yang berada atau berbatasan langsung dengan arus laut. Kondisi ini memudahkan terjadinya pertukaran propagul antar lokasi yang letaknya cukup berjauhan, sehingga tidak terjadi isolasi geografis antar populasi.

\section{Rhizophora apiculata $\mathrm{Bl}$.}

Kekhasan spesies mangrove Rhizophora apiculata di Gili Sulat tampak pada tinggi pohon (Tabel 1). Populasi pohon Rhizophora apiculata yang terdapat di Gili Sulat ada yang mencapai tinggi sampai $17 \mathrm{~m}$. Tinggi pohon jenis tersebut yang ditemukan di Pulau Lombok (termasuk Gili Sulat) adalah umumnya mencapai tinggi maksimum $16 \mathrm{~m}$ (Tabel 2).

Rhizophora apiculata merupakan spesies mangrove yang memiliki sebaran cukup luas di Gili Sulat. Spesies mangrove ini ditemukan membentuk populasi murni dan populasi campuran pada beberapa lokasi di Gili Sulat (Agil, 2013).

Keanekaragaman genetik populasi Rhizophora apiculata di Gili Sulat termasuk rendah. Ciri morfologi batang, akar dan jumlah bunga pada semua sampel populasi spesies yang diamati (Tabel 1) tidak menunjukkan perbedaan dengan ciri pada Tabel 2. Variasi morfologi yang tidak berbeda nyata antar sampel dalam populasi spesies tersebut diduga karena banyak terjadi penyerbukan sendiri. Hasil penelitian Yahya et al. (2014) dengan menggunakan bukti molekuler mikrosatelit menunjukkan bahwa variasi genetik dalam dan antar populasi Rhizophora apiculata yang terdapat di Kepulauan Sunda Besar tergolong rendah karena terbentuk populasi inbreeding akibat penyerbukan sendiri.

\section{Ceriops tagal C. B. Rob.}

Hasil pengamatan terhadap Ceriops tagal, menunjukkan bahwa anggota spesies tersebut memiliki dua populasi yang menunjukkan perbedaan morfologi yang cukup tegas (Tabel 1). Morfologi pembeda antara kedua populasi tersebut terdapat pada ciri tinggi pohon, batang, dan jumlah bunga. Populasi 1 memiliki tinggi 5-6 m, kulit batang berwarna abuabu, jumlah bunga pada setiap tandan 4-5. Populasi 2 dengan tinggi pohon 3-5 m, kulit batang berwarna abu sampai abu 
coklat, jumlah bunga pada setiap tandan 68. Walaupun kisaran ciri morfologi kedua populasi spesies Ceriops tagal tersebut berada dalam rentang toleransi ciri pada Tabel 2, namun ciri masing-masing populasi merupakan kekhasan mangrove di Gili Sulat. Perbedaan morgologi yang tegas antara beberapa populasi Ceriops tagal juga pernah dilaporkan oleh Liao et al. (2011) untuk populasi spesies yang terdapat di Laut Cina Selatan.

Ceriops tagal populasi 1 dan Ceriops tagal populasi 2 ditemukan pada tempat yang terpisah di Gili Sulat. Ceriops tagal populasi 1 ditemukan pada habitat yang tidak terlalu sering tergenang air laut di sisi utara komunitaas mangrove Gili Sulat. Ceriops tagal populasi 2 tumbuh pada jeluk-jeluk yang banyak digenangi air laut pada sisi timur komunitas mangrove Gili Sulat, yaitu pada formasi paling belakang. Jumlah populasi pada kedua lokasi tersebut cukup terbatas.

\section{Sonneratia alba J. Smith.}

Ciri khas mangrove anggota Sonneratia alba di Gili Sulat yaitu pada diameter batang. Hasil penelitian menunjukkan terdapat beberapa anggota populasi spesies tersebut yang diameter batangnya dapat mencapai $150 \mathrm{~cm}$ (Tabel 1). Ukuran tersebut merupakan diameter paling besar yang ditemukan di kawasan Pulau Lombok. Menurut informasi masyarakat di Takalok, Lombok Timur, pohon Sonneratia alba tersebut diperkirakan telah berusia lebih dari 100 tahun.

Pohon Sonneratia alba yang terdapat di Gili Sulat memiliki batang paling tinggi. Ukuran tinggi batang Sonneratia alba yang umumnya terdapat di Pulau Lombok dapat mencapai 16 meter (Tabel 2), sedangkan hasil penelitian di Gili Sulat menunjukkan bahwa beberapa individu pohon jenis tersebut dapat mencapai tinggi sampai $20 \mathrm{~m}$ (Tabel 1). Pohon-pohon Sonneratia alba yang memiliki batang yang tinggi tersebut merupakan habitat yang khas sebagai tempat istirahat populasi kelelawar. Dimasa lalu sampai tahun 1983 pohon Sonneratia alba yang terdapat di Teluk Sepi, Lombok Barat juga menjadi tempat istirahat kelelawar. Namun saat ini pohon Sonneratia alba di lokasi tersebut sudah semakin jarang ditemukan karena penebangan liar untuk arang dan kayu bakar.

\section{Avicennia marina (Forsk.) Vierh.}

Spesies Avicennia marina yang terdapat di Gili Sulat disusun oleh dua populasi yang dapat dibedakan secara morfologi (Tabel 1). Avicennia marina populasi 1 memiliki ciri tinggi pohon 6-11 $\mathrm{m}$, warna kulit batang abu bercak hijau, akar berupa pneumatofora, dan jumlah bunga pada setiap tandan 15-20. Ciri yang membedakan Avicennia marina populasi 1 dengan Avicennia marina populasi 2, bahwa pada populasi 2 tinggi pohon $5-8 \mathrm{~m}$ dan jumlah bunga 8-12 pada setiap tandan. Belum ada publikasi tentang temuan populasi-populasi anggota spesies Avicennia marina pada lokasi lain di Pulau Lombok. Dengan demikian adanya 2 populasi spesies Avicennia marina tersebut merupakan kekayaam variasi genetik yang khas untuk mangrove di Gili Sulat.

Status taksonomi kedua populasi spesies Avicennia marina yang terdapat di Gili Sulat belum dapat ditentukan. Penentuan status taksonomi kedua populasi tersebut pada tingkatan infraspesifik masih membutuhkan kajian taksonomi yang mendalam secara morfologi dan molekuler. Kajian taksonomi yang berbasis molekuler akan lebih akurat dalam menentukan perbedaan populasi-populasi pada spesies Avicennia marina seperti yang telah dilakukan oleh Said et al. (2010) terhadap empat 
heteroform Avicennia marina di Mesir dan oleh Hazarika et al. (2013) dalam analisis variasi genetik tiga populasi Avicennia marina menggunakan random amplified polymorphic DNA-polyerase chain reaction (RAPD-PCR) di India.

Kedua populasi Avicenia marina marina tersebut ditemukan pada formasi paling belakang dalam komunitas mangrove di Gili Sulat, namun pada jarak yang cukup jauh satu sama lain dan habitat yang berbeda. Avicennia marina populasi 1 ditemukan pada habitat yang tanahnya mendatar, sehingga populasi tersebut terbenam air laut pada saat pasang dan tidak digenangi air laut pada saat surut. Avicennia marina populasi 2 tumbuh pada jeluk-jeluk yang menyebabkan populasi tersebut selalu tergenang air laut baik dalam kondisi pasang dan surut. Karena kondisi tersebut, maka habitat tempat tumbuh Avicennia marina populasi 2 memiliki salinitas yang tinggi dibanding Avicennia marina populasi 1.

\section{SIMPULAN}

Spesies mangrove kelompok mayor (dapat membentuk tegakan murni) yang populasinya menunjukkan morfologi yang khas di Gili Sulat, yaitu Bruguiera gymnorrhiza, Rhizophora mucronata, Rhizophora stylosa, Rhizophora apiculata, Ceriops tagal, Sonneratia alba, dan Avicennia marina. Kekhasan ciri morfologi spesies mangrove tersebut mencakup karakter tinggi pohon, warna dan diameter batang, struktur akar dan jumlah bunga.

\section{DAFTAR PUSTAKA}

Agil, Al Idrus. 2013. Mangrove di Gili Sulat • Argapuji Press, Mataram Lombok.

Barbour, M.G., J.H. Burk, and W.D. Pitts. 1980. Terrestrial Plant Ecology. The
Benjamin/Cummings Publishing

Company, Inc., Menlo Park, California.

Hardjosuwarno, S. 1990. Ekologi

Tumbuhan. Fakultas Biologi, UGM, Yogyakarta.

Kitamura, S., C. Anwar, A. Cganiago, and S. Baba. Hanbook of Mangroves in Indonesia - Bali \& Lombok. The Development of Sustainable mangrove Management Project, Ministry of Forestryb Indonesia and Japan International Cooperation Agency.

Liao, Pei-Chun, Sgih-Ying Hwang, S. Huang, Yu-Chung Chiang and JennChe Wang. 2011. Contrasting demographic of Ceriops tagal (Rhizophoraceae) populations in the South China Sea. Australian Journal of Botany 59(6): 523-532.

Tomlinson, P.B. 1986. The Botany of Mangrove. Cambridge University Press, Cambridge, London, New York, N. Rochelle, Melborne, Sydney

Whitmore, T.C. 1961. Studies in Systematic Bark Morphology. I. Bark Morphology in Dipterocarpaceae. New Phytol: 191-207.

Yahya, AF., J.O. Hyun, YY. Kim, KM. Lee, KN. Hong, and SC Kim. 2014. Genetic variation and population genetic structure of Rhizophora apiculata (Rhizophoraceae) in the Greater Sunda Islands, Indonesia using microsatellite markers. J. Plant Res. 127 (2) 297-289.

Said, W.M. anda N. O.M. Ehsan. 2010. Morphological and Molecular Evidences Among Four Heteroforms of Avicennia marina (Forssk) Vierh. 
Journal of American Science 6 (11): 843-856.

Hazarika, D. M. Thangaraj, SK. Sahu, and K. Kathiresan. 2013. Genetic diversity in three population of Avicennia marina along the eastcost of India by RAPD markers. J. Environ Biol. 34(3): 663-666. 